\title{
Clinton sets up science and technology council
}

Washington. President Bill Clinton's new National Science and Technology Council (NSTC) will meet for the first time early in the new year, and will conduct an "across the board review" of US federal research spending during 1994 before delivering advice on the allocation of funds for the following fiscal year.

The council was first proposed in September, largely on the advice of the president's science adviser, John Gibbons (see Nature 365, 195; 1993) and was established last week by the president's executive order. It is intended to bring new cohesion to US science policy by bringing together the heads of all government agencies and departments responsible for spending on science, while saving money in the White House by streamlining existing structures.

As an early step towards the latter, the council will take over the responsibilities of the main such body, the Federal Coordinating Council for Science, Engineering and Technology (FCCSET), as well as those of two other groups, the National Space Council and the National Critical Materials Council. ton and includes all relevant cabinet ministers and presidential advisers, together with the heads of the National Science Foundation, the National Aeronautics and Space Administration and the Environmental Protection Agency. being held as required. According to one White House official this means anything from once a month to twice a year. by nine coordinating committees, whose areas of responsibility range from health to

\section{Saxony rejects appeals court verdict}

Munich. The German regional government of Saxony has refused to reinstate a Leipzig professor who has appealed successfully against his dismissal last August for alleged cooperation with Stasi, the former East Germany's secret police.

Hans Joachim Meyer, the Land's research minister, has refused to accept a court decision that Wolf-Dietrich Arnold, previously director of the University of Leipzig's Orthopaedic Clinic, should be given his job back. Indeed, Meyer has approved the provisional offer of his job to a new applicant for the position, pending the decision of a higher court.

Arnold, who has the support of most members of his department, has always denied the charge that he used his membership of the Communist party to the disadvantage of the careers of his students and staff (see Nature 359, 762; 1992). He claims that he joined the party only five years before reunification to make his professional life easier by increasing his political contacts.

Arnold is one of thousands of academics in the former East Germany who have been dismissed during the reorganization of the universities that followed reunification. Hundreds have appealed against the decisions, and at least 14 appeals in Saxony have been successful. But Meyer has challenged them all, saying that he will continue to fight any victory as a matter of principle.

Arnold's case was the last to be heard. On 15 October, the research minister offered to settle, a move that would have given victory to Arnold after an obligatory four-week 'consideration period' during which either party has the right to change its mind. Shortly before the end of this period, however, Meyer withdrew the offer and announced that he would be appealing to a higher court.
This case comes up next month. Meanwhile -- and in defiance of court decisions - Meyer has allowed the University of Leipzig to seek a replacement for Arnold. The selection process has already taken place, and the directorship has been offered, in principle, to a new candidate. Legally the post cannot be definitively offered unless the higher court rules in favour of Meyer.

A spokesman for the ministry said that it could make no comment while the court case was pending. But Arnold believes it is "monstrously unfair" of Meyer to pre-empt a court decision and decide on a successor in this way.

Alison Abbott
The full council will be chaired by Clin-

But meetings will not be regular, only

The real work of the council will be done

international collaboration. These committees will consist of less senior government officials, and will meet much more frequently than the main council. Additional ad hoc working groups will be established as required.

Tim Newall, a staff member of the White House's Office of Science and Technology Policy, says that the overall review promised by Clinton will feed into the budget process next year, culminating in the president's budget proposals for the financial year starting in October 1995, which must be ready by January 1995 .

Clinton has also established a President's Committee of Advisors on Science and Technology (PCAST) to provide input into the advisory process from the private sector. The committee members and the name of the industrialist who will chair it jointly with Gibbons, will be named early next year.

According to Newall, PCAST will differ from previous panels of its type because it will aim to make direct contact with US industry through active subcommittees, "instead of just meeting once a month in Washington".

Officials say the cabinet-level NSTC is proof of the Clinton administration's commitment to science and technology, and that its responsibilities will mirror those of the powerful National Security Council.

But the existence of the new body by no means assures that it will carry clout. Science and technology priorities in the United States tend to be set independently by government departments and other agencies; their defenders in Congress are likely to oppose any attempt to centralize decisionmaking.

Colin Macilwain

\section{Mathematics inspires office of the future}

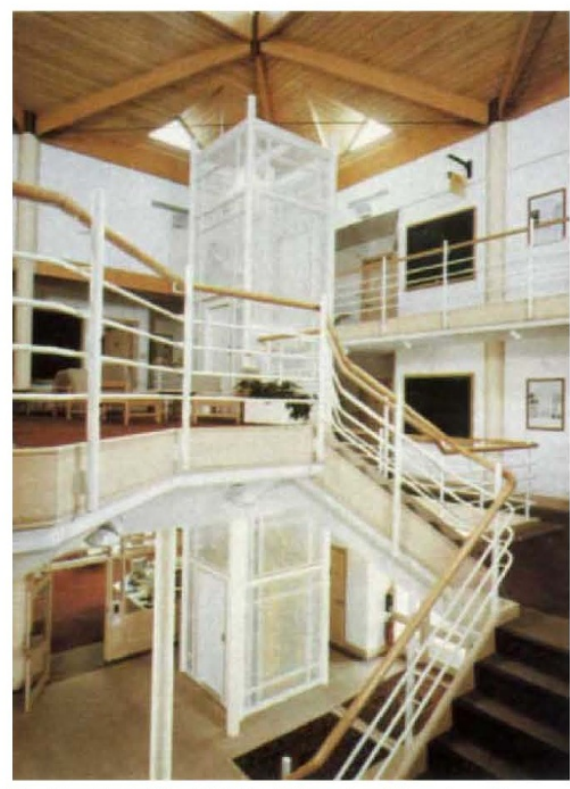

Mathematicians visiting the Isaac Newton Institute for Mathematical Studies in Cambridge, England (left) may be excused for finding themselves stimulated as much by the bricks and mortar as the scientific debate going on within the building.

The institute, opened in June last year, has won the 1993 Office of the Year Award for Innovation sponsored by DuPont (UK) Ltd. The judges described it as "a model for commercial buildings of the future where professional and knowledge [sic] workers will be employed in greater numbers".

The focus of the building, designed by Duncan Annand, a local architect, is an open common room where researchers can 'brainstorm' on the blackboards that decorate the walls as they meet over coffee. The institute brings together researchers from different countries and disciplines, usually for a relatively short period of time.

Fiona Gammie 